\title{
The Effect of The Realistic Mathematics Education (RME) Approach and The Initial Ability of Students on The Ability of Student Mathematical Connection
}

\author{
Febriyanti' 1 , Riana Bagaskorowati ${ }^{2}, \&$ Makmuri $^{2}$ \\ ${ }_{1}$ Postgraduate Basic Education, Universitas Negeri Jakarta, Jakarta Timur, 13220, Indonesia \\ 2 Universitas Negeri Jakarta, Jl. Rawamangun Muka, Jakarta Timur 13220, Indonesia \\ azkiapermis_bangka@yahoo.com; riana_gunadi@yahoo.com; makmuri@unj.ac.id \\ *Corresponding Author \\ Whatsapp number: [+62-81932027169]
}

How to Cite : Febriyanti, F., Bagaskorowati, R., Makmuri, M. (2019). The Effect of The Realistic Mathematics Education (RME) Approach and The Initial Ability of Students on The Ability of Student Mathematical Connection. International Journal for Educational and Vocational Studies, 1 (3), 153-156.

\section{ARTICLE HISTORY}

Received: 8 June 2019

Revised: 12 July2019

Accepted: 24 July 2019

\section{KEYWORDS}

Realistic Mathematics Education (RME), Initial Capability,

Connection Mathematics,

\begin{abstract}
This study aims to determine the effect of the Realistic Mathematics Education (RME) approach and students' initial ability to mathematical connection skills of students in grade III of elementary school. The method used is the experimental method with $2 \times 2$ treatment by level design with 30 samples. Data analysis using two-way analysis of variance and followed by the Tukey test for the significance level $a=0.05$. Test the normality of the data using the Lilliefors test and homogeneity test using the Bartlett test. The results of the study show that: 1). Mathematical connection skills in students taught by the Realistic Mathematics Education (RME) approach are higher than students taught by conventional approaches. 2). There is an interaction between the use of the learning approach and the students 'initial ability to students' mathematical connection skills. 3).Ability of mathematical connection of elementary school students between students who study using the Realistic Mathematics Education (RME) approach that has a high initial ability higher than students who learn by using a conventional approach that has high initial abilities. 4) The mathematical connection ability of elementary school students between students who study with the Realistic Mathematics Education (RME) approach that has low initial abilities is higher than students who learn with conventional approaches that have low initial abilities.
\end{abstract}

This is an open access article under the CC-BY-SA license.

\section{INTRODUCTION}

Mathematics as queen of science or mother of science, which means that mathematics is a source of other knowledge. There are so many sciences, their discovery and development depends on mathematics. (Andriani, 2008). One field of study which is an important part in an effort to improve the quality of education in Indonesia is mathematics because mathematics has an important role in everyday life as well as in other sciences. The importance of mastery of mathematics can be seen in Law No. RI. 20 of 2003 concerning National Education System Article 37 affirms that mathematics is one of the compulsory subjects for students at the elementary and secondary education level.

Mathematics in Elementary School is the beginning of a student to explore his ability to understand mathematical concepts and knowledge that is right and good. Mathematics is a hierarchical, continuous lesson, so the mathematical concepts learned by elementary school students must be correct, if the elementary mathematics concept is wrong then it will impact on further education. mastery of mathematics material at the previous level of education is very necessary because it is the initial ability of students in learning mathematical material at the next level. (Trianto, 2007) explaining initial abilities is a set of individual knowledge and experience gained throughout the course of their lives, and what he brings to a new learning experience. Whereas (Dick \& Carey, 2005) says that the initial ability is knowledge or skills that have been possessed by students before he follows the subjects to be given. With this initial ability students can learn the material to be taught by the teacher and vice versa without this initial ability students will have difficulty learning the next material. 
Mastery of the material in mathematics is very much influenced by the initial abilities possessed by students at the previous school level to the present level because the concepts in mathematics are related to one another. The interrelationship between material concepts one and the other is evidence of the importance of students' initial ability to understand mathematical concepts. Therefore, students cannot understand a material if they have not understood the previous material or the prerequisite material of the material to be studied. (Novitasari, 2016). The ability to connect concepts in mathematics is called mathematical connection ability. A good initial ability of students will help good mathematical connection skills and vice versa. Therefore the students' initial ability to understand mathematical concepts and mathematical connection skills is one of the main objectives of mathematics learning in elementary schools.

Mathematical connection is the ability of students to find a relationship between a representation of concepts and procedures, understanding between mathematical topics, and the ability of students to apply mathematical connections in other fields or in everyday life. (Widarti, 2008). Students' mathematical connection ability is one aspect of important mathematical abilities that must be achieved through mathematics teaching and learning activities, because by knowing the mathematical relationships students will better understand mathematics and also give them greater mathematical power. mathematical connection ability is a person's ability to show internal and external relationships of mathematics, which includes connections between mathematical topics, connections with other scientific disciplines, and connections with everyday life. (Sugiman, 2008).

Mathematics is one of the important lessons when viewed from the description above, behind the fact that it is important for early abilities and mathematical connection skills for students, the existing situation shows the opposite results. The results of mathematics learning in Indonesia are still apprehensive, as seen from the results of research conducted by the PISA (Program of International Study Assessment) in 2015. The mathematical abilities of Indonesian students score 386 below the international score average, which is 490. (PISA, 2016). In addition, Indonesia's score in the Trends in the International Mathematics and Science Study (TIMSS) in 2015 amounted to 397 was far from scale centerpoint Timss which was equal to 500 and ranked 44th out of 50 participating countries. The TIMSS score in 2011 was 392 which increased to 397 in 2015 but Indonesia's score was still low compared to other countries. (TIMSS, 2015). This is one proof that the results of mathematics learning are not yet at a satisfactory level.

This problem also occurs in students at SDN Jurang Mangu Barat 01 South Tangerang. Based on observations in class III of SDN Jurang Mangu Barat 01 South Tangerang in November 2018, information was obtained that mathematics learning still used a traditional or conventional approach, mathematics learning was still teacher-centered, students active in conveying ideas or opinions to solve mathematical problems still low, students' initial ability is still low, mathematics learning is still fixed by the book. many students lack understanding of mathematical material especially in fraction material whereas fraction material is one of the most important mathematical material, because it is the basis for further learning of mathematics, and is widely used in daily life and in other fields. (Darma, Sadra and Sariyasa, 2013). The difficulty of the fraction material experienced by students at SDN Jurang Mangu Barat 01 South Tangerang is due to various factors such as the lack of linking teaching material with students' problems in daily life, students find it difficult to arrange their own models to solve real problems and express day-to-day events days in the language of mathematics.

According to Kenedi, et al (2018) in his research about on students' mathematical connection skills with research results according to indicators of mathematical connection ability, namely, the first indicator recognizes and utilizes the relationship between ideas in mathematics with scores obtained at 67.71 , the second indicator recognizes and applying mathematics in everyday life with scores obtained at 48.66, and the third indicator understands how ideas in mathematics are interconnected and underlie one another to produce a coherent whole that gets an average score of 57.14.

Based on data from the research results it can be concluded that the mathematical connection ability of elementary school students is still relatively low. In this description the mathematical connection ability becomes very important because it will help mastering mathematical concepts that are meaningful and help solve problem solving tasks through the interrelationship between mathematical concepts and between mathematical concepts and concepts in other disciplines. Likewise this mathematical connection ability will help students in compiling mathematical models that also describe the interrelationships between concepts or data of a problem or situation given. (Utari, 2012). The goal of mathematics education will not be achieved if students cannot realize and associate mathematics learning with everyday life, students tend to distinguish between school and home even though it is only considered accidental even though mathematics is learned to help life.

In the previous research on research used the Realistic Mathematics Education (RME) approach conducted by Kurino in 2017 showed that the Realistic Mathematics Education (RME) approach from the results of the research obtained each cycle experienced an increase. The average learning outcomes of the first cycle reached 52.25 , the average learning outcomes of Cycle II was 74.34 , and the average learning outcomes of the third cycle reached 92.34 (Kurino, 2017).

Thus it can be concluded that the Realistic Mathematic Education (RME) learning approach can be used as a reference for researchers in research to see students' initial abilities and mathematical connection skills of elementary school students. Based on the description of the problem described above, to bring out and improve students' initial abilities and mathematical connection skills, an alternative learning approach that takes fundamental changes is more focused on replacing mechanistic mathematics learning to be realistic in this case the researcher presents an approach that is widely expected by a number of Indonesian mathematicians who can make students active and make mathematics learning 
more meaningful namely the Realistic Mathematics Education (RME) Approach.

In order to realize quality education, the government has set a 2013 curriculum to be applied to Elementary Schools. The successful implementation of teaching and learning activities is very dependent on the teacher, because the teacher is the spearhead in the learning process. In this 2013 curriculum, students are required to find out, not be told, so as to encourage students to creativity and construct their own knowledge. Lessons in realistic mathematics learning are developed from everyday life situations, namely from what has been heard, seen or experienced by students. The situations and activities in everyday life that have been felt or encountered by students are the knowledge they have informally. Therefore, in providing learning experiences to students it should start from something real/real for students. (Ningsih, 2014). Fractional material is very suitable to be taught using the Realistic Mathematics Education (RME) approach, because realistic mathematical approaches have characteristics and principles that enable students to develop optimally, such as the freedom of students to express their opinions, contextual problems that can relate mathematical concepts to real life, and making models that can facilitate students in solving problems. (Marhamah, Zulkardi and Aisyah, 2011).

Realistic Mathematics Education (RME) is a mathematics that places the reality and experience of students as the starting point of learning. Realistic problems are used as sources of emergence of mathematical concepts or formal mathematical knowledge. This learning is very different from mathematics learning so far. According to Gravemeijer the main idea of the realistic mathematical approach is that students must be given the opportunity to reinvent mathematical ideas and concepts with adult guidance through exploring various situations and problems in the real world or real world. (Saragih, 2016).

Based on the background described above, research will be conducted by looking at the influence of the Realistic Mathematics Education (RME) approach and the students' initial ability to mathematical connection skills. Therefore, this study will be entitled "The Effect of Realistic Mathematics Education (RME) Approach and Students' Early Ability to Mathematical Connection Ability of Class III Elementary School Students at SDN Jurang Mangu Barat 01 South Tangerang".

\section{METHODS}

In this study the method used was a quantitative experimental approach with a 2x2 treatment by level factorial design to compare two different students' mathematical connection abilities, namely between mathematical connection skills using the Realistic Mathematic Education (RME) learning approach and mathematical connection skills using conventional learning approaches with variable attributes of students' initial abilities.

The time for conducting this study is the second semester of the 2018/2019 academic year, May to June 2019. The sample of the study was class III A and III B students at Jurang Mangu Barat State Elementary School 01 South Tangerang. Sampling in this study was carried out by stratified multistage cluster random sampling technique. Data collection to measure mathematical connection skills is done using written essay instruments. Whereas to measure students' initial abilities using written instruments in the form of multiple choice questions.

Testing the validity of mathematical connection skills using construct validity is by using expert judgment, which is to consult instruments to expert lecturers as experts. After that, panel validity was tested to 30 students using the Pearson formula, namely Product Moment and reliability using the Cronbach Alpha formula. In order for hypothesis testing to be carried out, it is necessary to test the analysis requirements, namely the normality test and homogeneity test. The normality test was carried out by the Liliefors Test and the homogeneity test was carried out by the Barlett Test. The testing of the research hypothesis proposed using analysis of variance (ANAVA). Then using the further test, the Tukey test.

\section{RESULTS AND DISCUSSION}

\section{Results}

Based on normality data calculations in all group studies noted that Lcount is smaller than Ltable, this means that in all study groups normal distribution. The results of the normality test with the Liliefors test as a whole can be seen in the table 1.

Table 1. Recapitulation of Sample Normality Test Results with Test Liliefors at the level of $a=0.05$

\begin{tabular}{ccccc}
\hline Group & Number of Samples & $L_{\text {count }(\text { Lo })}$ & $L_{\text {table }}\left(\mathbf{L}_{\mathbf{t}: \boldsymbol{\alpha}=\mathbf{0}, \mathbf{0 5})}\right.$ & Conclusion \\
\hline $\mathrm{A}_{1}$ & 20 & 0,181 & 0,190 & Normal \\
\hline $\mathrm{A}_{2}$ & 20 & 0,180 & 0,190 & Normal \\
\hline $\mathrm{A}_{1} \mathrm{~B}_{1}$ & 10 & 0,184 & 0,258 & Normal \\
\hline $\mathrm{A}_{1} \mathrm{~B}_{2}$ & 10 & 0,139 & 0,258 & Normal \\
\hline $\mathrm{A}_{2} \mathrm{~B}_{1}$ & 10 & 0,143 & 0,258 & Normal \\
\hline $\mathrm{A}_{2} \mathrm{~B}_{2}$ & 10 & 0,147 & 0,258 & Normal \\
\hline
\end{tabular}

While the recapitulation of the results of homogeneity test data using the Barlett test where $X^{2}$ count $<X^{2}$ table at the significance level $a=0.05$ can be seen in the following table: 
Table 2. Recapitulation of Homogeneity Tests in Groups Research Using the Barlett Test $(a=0.05)$

\begin{tabular}{|c|c|c|c|c|c|c|}
\hline Group & Variants $\mathbf{S}^{2}$ & $\begin{array}{l}\text { Variants Combination } \\
\mathrm{S}^{2}\end{array}$ & Value B & $X_{\text {count }}$ & $X_{\text {table }}$ & Information \\
\hline$A_{1} B_{1}$ & 2,7 & \multirow{4}{*}{2,978} & \multirow{4}{*}{17,064} & \multirow{4}{*}{0,352} & \multirow{4}{*}{7,81} & \multirow{4}{*}{ homogeneous } \\
\hline$A_{1} B_{2}$ & 2,49 & & & & & \\
\hline$A_{2} B_{1}$ & 3,53 & & & & & \\
\hline$A_{2} B_{2}$ & 3,19 & & & & & \\
\hline
\end{tabular}

Based on the results of testing the normality and homogeneity of research data, it can be concluded that the data comes from a population that is normally distributed and homogeneous, so that it can be followed by testing the hypothesis. The calculation has been done using the two-way ANOVA analysis obtained as in the table 3.

Table 3. Results of Analysis of Variance Using Anava Two-way

\begin{tabular}{|c|c|c|c|c|c|c|}
\hline \multirow{2}{*}{ Source of Variants } & \multirow{2}{*}{$\mathrm{Db}$} & \multirow{2}{*}{ JK } & \multirow{2}{*}{ RJK } & \multirow{2}{*}{$F_{\text {count }}$} & \multicolumn{2}{|c|}{$F_{\text {table }}$} \\
\hline & & & & & 0,005 & 0,01 \\
\hline Between Columns & 1 & 302,5 & 302,5 & 76,58 & 4,11 & 7,39 \\
\hline Between Lines & 1 & 2722,5 & 2722,5 & 689,24 & 4,11 & 7,39 \\
\hline Interaction & 1 & 103,6 & 103,6 & 26,23 & 4,11 & 7,39 \\
\hline Inside & 36 & 142,2 & 3,95 & & & \\
\hline Total Reduction & 39 & 3270,8 & & & & \\
\hline
\end{tabular}

Based on table 3 shows that the calculation of ANOVA $2 \times 2$ shows the results of the calculation of variance analysis about the difference in effectiveness between the two learning approaches as a whole that $\mathrm{F}$ count $(\mathrm{A})=76.51>$ Ftable $=4.11$ at the significance level $\alpha$ $=0.05$, thus Ho rejected. Then the mathematical connection ability between groups of students was given a higher Realistic Mathematic Education (RME) learning approach than the group of students given a conventional approach.

The results of calculation of ANOVA $2 \times 2$ can be concluded that there are significant differences in influence between groups given the Realistic Mathematic Education (RME) learning approach and groups of students given conventional approaches to students' mathematical connection skills. Therefore the mathematical connection ability given the Realistic Mathematic Education (RME) learning approach $(\overline{\mathrm{x}}=80.3)$ is significantly better than that given the conventional approach $(\bar{x}=74.8)$. This means that the overall research hypothesis is the mathematical connection ability that is given a higher Realistic Mathematic Education (RME) learning approach compared to the group of students given a conventional approach.

Based on the ANAVA calculation results, it can be seen that the results of testing the second hypothesis presented in the ANAVA table on the AXB interaction line indicate that $\mathrm{Ho}$ is rejected based on the value that Fcount $(\mathrm{AB})=26.23>\mathrm{F}_{\text {table }}=4.11$ thus it can be concluded that there are significant interactions between the learning approach and the students' initial ability to the mathematical connection skills. Based on the research data, the average score of mathematical connection ability between groups of students with high initial abilities given the Realistic Mathematic Education (RME) learning approach is 88.2 and given the conventional approach is 83.3.

Based on the results of the analysis show that the Tuckey test $\mathrm{A}_{1} \mathrm{~B}_{1}>\mathrm{A}_{2} \mathrm{~B}_{1}=\mathrm{Q}_{\text {count }}=7.80$ greater than $\mathrm{Q}_{\text {tabel }}$ $(\alpha=0.05)=2.04$ or $Q_{\text {count }}>Q_{\text {tabel }}$ the significance level $\alpha=$ 0.05 thus $H_{o}$ is rejected. It is known that the average value of the $\mathrm{A}_{1} \mathrm{~B}_{1}$ group is $88.2>\mathrm{A}_{2} \mathrm{~B}_{1}=83.3$, it can be concluded that the mathematical connection ability of students given the Realistic Mathematics Education (RME) learning approach and those who have high initial abilities is higher than the group of students given conventional learning approaches and those with high initial abilities.

Based on the results of the analysis indicate that the calculation of the Tuckey test $A_{1} B_{2}>A_{2} B_{2}=Q_{\text {count }}=9.70$ is greater than $Q_{\text {tabel }}(\alpha=0.05)=2.04$ or $Q_{\text {count }}>Q_{\text {table }}$ at the significance level $\alpha=0.05$ thus $\mathrm{Ho}$ is rejected. It is known that the average value of the $\mathrm{A}_{1} \mathrm{~B}_{2}$ group is $72.3>$ $\mathrm{A}_{2} \mathrm{~B}_{2}=66.2$, it can be concluded that there is a difference between the mathematical connection ability of students given the Realistic Mathematics Education (RME) learning approach and those who have lower initial abilities higher than the group students given conventional learning approaches and those with low initial abilities.

\section{Discussion}

The research findings revealed that there were differences between students who were given a Realistic Mathematic Education (RME) learning approach and students given a conventional approach. The results showed that the mathematical connection ability of students given the Realistic Mathematic Education (RME) learning approach was higher than students who were given a conventional learning approach. Based on these differences, it can be 
explained that the Realistic Mathematic Education (RME) learning approach is a learning approach that provides students with opportunities to share ideas, discuss between groups to exchange opinions or ideas and to be able to rediscover mathematical ideas or concepts through exploration of real problems.

In accordance with the opinion (Lestari and Yudhanegara: 2015) Realistic Mathematic Education (RME) is school mathematics carried out by placing the reality and experience of students as the starting point of learning. Realistic problems are used as sources of emergence of mathematical concepts or formal knowledge that can encourage problem solving activities, find problems, and organize the subject matter. With these characteristics, a high initial ability is needed so that students can participate in classroom learning well. Unlike the conventional approach, in the conventional approach to teacher-centered learning, almost all learning activities are fully controlled by the teacher. The entire system is directed to a series of events that are neat in educational institutions, without any attempt to find and apply different learning approaches according to the themes and learning difficulties of each individual.

Interaction implies the existence of cooperation between two independent variables in influencing the dependent variable. The significance of this interaction will affect the form of interaction that occurs. This means that the influence of interactions will have important meaning if testing is carried out from each level of treatment. Based on the research findings that there is an influence of the interaction between the learning approach and the students' initial ability to the ability of mathematical connection skills. The results obtained explained that the group of students who had high initial abilities and were given a Realistic Mathematic Education (RME) learning approach, the mathematical connection abilities obtained were higher than those given conventional learning approaches.

In the group of students who had low initial abilities and were given a Realistic Mathematic Education (RME) learning approach higher than conventional learning approaches. (Darwyan Syah: 2009) says that in teaching activities when choosing an increasingly used learning approach, the more effective and efficient learning activities carried out between teachers and students will ultimately support and deliver the success of student learning and the success of teaching conducted by the teacher. Students who have high initial abilities given the Realistic Mathematics Education (RME) approach show greater mathematical connection skills than students given conventional approaches. Students who have low initial abilities given the Realistic Mathematics Education (RME) approach show greater mathematical connection skills than students given the Conventional approach. This shows that in providing the right learning approach must pay attention to students' initial abilities.

The research findings revealed that there were differences in mathematical connection skills in groups of students given the Realistic Mathematics Education (RME) learning approach and those with high initial abilities with groups of students who were given conventional learning approaches and had high initial abilities. The results showed that the mathematical connection ability in the group of students given the Realistic Mathematics Education (RME) learning approach was higher than the group of students given the conventional learning approach and those with high initial abilities. (Uno: 2011) explains that "initial ability is very important role in increasing the meaningfulness of teaching, which then has an impact in facilitating internal processes that take place in students when learning.

The research findings revealed that there were differences in mathematical connection skills in groups of students given the Realistic Mathematics Education (RME) learning approach and those with low initial abilities with groups of students given conventional learning approaches and those with low initial abilities. The results obtained showed that the ability of mathematical connections in groups of students given a higher Realistic Mathematics Education (RME) learning approach was compared to groups of students who were given conventional learning approaches that had low initial abilities. As expressed by (Gora and Sunarto, 2010) that a conventional approach views the learning process carried out as teachers generally teach material to students.

The teacher transfers knowledge to students, while students play more roles as recipients or passively hear and receive direction from the teacher. Students who have low initial abilities lack initiative with or without the help of others, in determining their learning needs, determining their learning goals, determining their learning facilities, choosing and implementing appropriate learning strategies and assessing their learning outcomes. With these characteristics, the suitable applied for students who have low initial abilities is the Realistic Mathematics Education (RME) approach where in this approach students can learn from topics or material that have been determined by the teacher through learning mathematics that uses realistic problems as a source of emergence of mathematical concepts or formal knowledge that can encourage problem solving activities, find problems, and organize the subject matter.

\section{CONCLUSION}

Based on the results of the study and discussion of the learning approach and initial ability to the mathematical connection skills in the fraction material in classes III A and III B at Jurang Mangu Barat Elementary School 01 South Tangerang, it was concluded that:

1. The ability of mathematical connections to students taught by the Realistic Mathematics Education (RME) 
approach is higher than students taught by conventional approaches. This can be explained that the Realistic Mathematics Education (RME) approach is a learning activity that involves students who can learn through real or existing objects in the student's environment. While the conventional approach is learning that prioritizes the learning process where the task of the teacher is only to deliver material to help students complete the learning process in the classroom. So it can be concluded that to improve the ability of mathematical connections it is more appropriate to use the Realistic Mathematics Education (RME) approach.

2. There is an interaction between the use of learning approaches and students' initial ability to mathematical connection skills. This is proven after research with a graph of the interaction between the learning approach and the students' initial abilities. Because the Realistic Mathematics Education approach to the students' initial ability of high mathematical connection skills obtained by students is also high while the mathematical connection ability in conventional approaches with low initial abilities results are higher than the mathematical connection ability in the Realistic Mathematics Education approach.

3. The mathematical ability of elementary school students to connect between students who study using the Realistic Mathematics Education (RME) approach that has a high initial ability is higher than students who learn by using a conventional approach that has high initial abilities.

4. The mathematical ability of elementary school students to connect between students who learn with the Realistic Mathematics Education (RME) approach that has a low initial ability is higher than students who learn with conventional approaches that have low initial abilities.

Based on the description above, it can be concluded that the learning approach and initial abilities influence the mathematical connection skills. Therefore, to improve students' mathematical connection skills, the use of learning approaches and initial abilities given by students is very helpful.

\section{REFERENCES}

Andriani Melly. (2008). Matematika sebagai Bahasa. Jurnal At-Tarbawi, Vol.7 Sukoharjo: STAIN (1). 70-90.

Carey. L. W. Dick. (2005). The Systematic Design of Instructional Third Boston: Pearson. h.6.

Darma Nyoman. Sadra I Wayan dan Sariyasa. (2013). Pendidikan Matematika Realistik Terhadap Pemahaman Konsep dan Daya Matematika Ditinjau Dari Pengetahuan Awal Siswa SMP Nasional Plus Jembatan Budaya. E Journal, Volume 2. Program
Pascasarjana Universitas Pendidikan Program Studi Pendidikan Matematika. (2).2-25.

Darwyan Syah. (2009). Strategi Belajar Mengajar. Jakarta: Diadit Media. h.19.

Gora Winastwan dan Sunarto. (2010). Pakematik Strategi Pembelajaran Inovatif Berbasis TIK. Jakarta: Elex Media Komputindo.h.50.

Hamzah B. Uno. 2011. Perencanaan pembelajaran. Jakarta: PT. Bumi Aksara.h.120.

Karunia Eka Lestari dan Mokhammad Ridwan Yudhanegara. (2015). Penelitian Pendidikan

Matematika. Bandung: Refika Aditama.h.15-16.

Kenedi Ary Kiswanto. (2018) Kemampuan Koneksi Matematis Siswa Sekolah Dasar Dalam Memecahkan Masalah Matematika. Jurnal Numeracy Vol.5 (2) Universitas Negeri Padang.231-145.

Kurino Yeni Dwi. (2017). Penerapan Realistic Mathematic Education Dalam Meningkatkan Hasil Belajar Siswa Kelas V Pada Materi Volume Bangun Ruang Di Sekolah Dasar. Jurnal Cakrawala Pendas. Vol. 3 No.2. p-ISSN: 2442-7470 e-ISSN: 2579-4442.45-47.

Ningsih Seri. (2014). Realistic Mathematics Education (RME) Model Alternatif Pembelajaran Matematika Sekolah. Jurnal JPM IAIN Antasari. Vol. 01 (2). 7-23.

Novitasari Dian. (2016). Pengaruh Penggunaan Multimedia Interaktif terhadap Kemampuan Pemahaman Konsep Matetamtis Siswa. Jurnal Pendidikan Matematika \& Matematika. Universitas Muhammadiyah Tangerang: Voleme 2 (2).1-13.

Marhamah, Zulkardi, dan Aisyah Nyimas. (2011). Pengembangan Materi Ajar Pecahan dengan Pendekatan PMRI Di SD Negeri 21 Palembang. Jurnal Pendidikan Matematika. Volume 5 (2).15-18.

PISA. Programme for Internasional Student Assessment (2015) Result: Excellence And Equity In Education. Volume 1. Paris: OECD publishing 2016.h.205.

Razak Firdha. 2017 "Hubungan Kemampuan Awal Terhadap Kemampuan Berfikir Kritis Matematika Pada Siswa Kelas VII SMP Pesantren Immim Putri Minasatene". Jurnal "Mosharafa", Volume 6 Nomor 1. P ISSN:4280; e-ISSN: 2527-8827 Pendidikan Matematika. STKIP Andi Matappa. $2-16$.

Saragih Sahat. (2006). Menumbuh Kembangkan Berfikir Logis dan Sikap Posotif Terhadap Matematiaka Melalui Pendekatan Matematika Realistik. Jurnal Pendidikan Dan Kebudayaan.559-568.

Siti Nur'aini Erna. Irawati Riana dan Julia. (2016). Pengaruh Pendekatan Realistic Mathematics Education (RME) Terhadap Kemampuan Pemahaman Matematis Dan Kepercayaan Diri Siswa Pada Materi Menyederhanakan Pecahan. Jurnal Pena Ilmiah. Vol. 1. (1) Program Studi PGSD UPI Sumedang. 11-25. 
Sugiman. (2008). Koneksi Matematika Dalam Pembelajaran Matematika Di Sekolah Menengah Pertama. Jurnal UNY Yogyakarta. (1).40-50.

TIMSS. Highlights from TIMSS (2015). Mathematics and Science Achievement of U.S. Fourth-and Eighth-Grade Students in an International Context. Washington. DC: U.S. Department of Education.h.165.

Trianto. (2007). Model-Model Pembelajaran Inovatif Berorientasi Konstruktivistik. Jakarta: Prestasi Pustaka.h.35-40.

Utari Sumarmo. (2012). Bahan Ajar Mata Kuliah Proses Berpikir Matematik Program S2 Pendidikan Matematika. Bandung :STKIP Siliwangi.h.10.

Wahyudi. (2016). The Development of Realistic Mathematics Education (RME) Model for the Improvement of Mathematics Learnings of Primary Teacher Education Program (PGSD) Students of Teacher Training and Education Faculty (FKIP) of Sebelas Maret University in Kebumen. Proceeding The 2nd International Conference On Teacher Training and Education Sebelas Maret University. Volume 2. (1). ISSN: $25002-4124$.

Widarti Arif. (2008) Kemampuan Koneksi Matematis Dalam Menyelesaikan Masalah Kontekstual Ditinjau dari Kemampuan Matematis Siswa. Jurnal STKIP PGRI Jombang. (1).255-230. 